\title{
Economic Stimulus Policies Implementation and Their Role in Empowering Indonesian SME's During Covid- 19 Pandemic: The Urgently VS Threat
}

\author{
Susan Purnama* and Fitriani Reyta \\ Faculty of Economics and Business, Universitas Informatika dan Bisnis Indonesia, Bandung, Indonesia. \\ *Corresponding author. Email: susanpurnama675@gmail.com
}

\begin{abstract}
In an uncertain economic situation like now, the MSME's sector is still believed to be a supporting force for the national economy. They are said to be the cogs of the Indonesian economy. In fact, this sector is said to have contributed greatly to the development and growth of this country. From the above description, it must be admitted that the MSME's sector has indeed become a mainstay in absorbing labor, substituting for consumption, or semi-finished products. Naturally, if the government is very concerned about ensuring that micro and small businesses continue to run and get stronger even in uncertain economic conditions. To support MSME's to become economic drivers, the government has planned to issue a stimulus for MSME's. With the stimulus, it is hoped that it will encourage the growth of competitive MSMEs during pandemic Covid-19 by cash fund transferred who called "BLT" in Indonesia means "Bantuan Langsung Tunai" a cash transfer direct to MSME's sector, the problem is the threat above the stimulus given are the spreading of covid -19 virus that haunted among BLT receiver, the system that not supported the covid-19 handling, a thousand BLT receiver are gathered in every city in Indonesia, the question is are this effective in empowering SME's, or become a threat to their lives? This qualitative research uses data collection methods in the form of observation, interviews, and documentation. Data collection was done in natural settings (natural conditions). Discussion on the results of this study will be presented based on the above research problem formulation.
\end{abstract}

Keywords: Economic Stimulus, SME's, Social Distancing, Covid-19, Empowerment

\section{INTRODUCTION}

To support MSME's to become economic drivers, the government has planned to issue a stimulus for MSME's. With the stimulus, it is hoped that it will encourage the growth of competitive MSMEs and give greater contributions to the national economy; the tax incentive design is expected to encourage the growth of the middle to the lower-scale business sector. Likewise about funding, this sector has also received various facilities. One of them is the reduction of the People's Business Credit (KUR) interest rate from $7 \%$ to $6 \%$. The government really understands that this sector is a buffer for the national economy. Likewise, with the increase in KUR Micro from IDR 25 million to IDR 50 million per Debtor. Not to mention, the Government's Job Creation Bill makes it easier for everyone who wants to form MSMEs. If all this time it is necessary to form a Limited Liability Company (PT), in this bill to create MSMEs only requires a Business Identification Number (NIB). Eempowerment is an effort to building that power, by encouraging, motivating, and raise awareness of its potential and strive to develop it, Indonesian government through Ministry Of Cooperative and MSME's set the public policy that developed from agenda setting that people who's been unemployment by Corona Virus and also MSME's that been hit by corona virus can be empowered by cash fund transferred who called "BLT" in Indonesia means "Bantuan Langsung Tunai" a cash transfer direct to MSME's sector [1]. Community empowerment is a concept of improving people's welfare in development. Development and the empowerment process are inseparable because to achieve a development goal the process that needs to be passed is to empower the community hence a community empowerment is realized 
in development. Empowerment is the concept most often used in community capacity building activities that emphasize the independence of the community. Community empowerment is an effort to improve the dignity of the layers of society who are now unable to escape the poverty trap and underdevelopment [2].

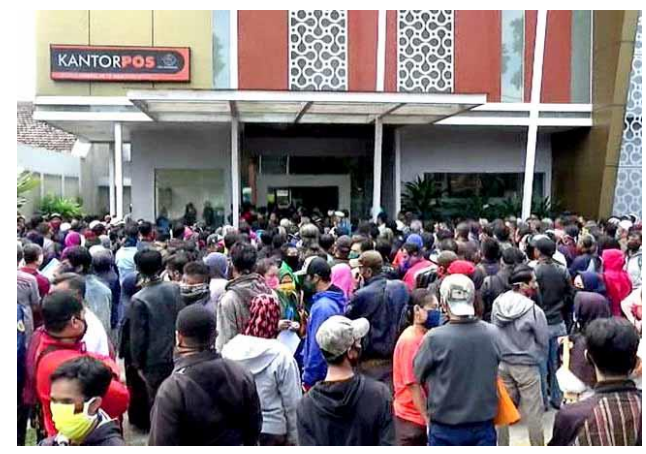

Figure 1. Implementation Cash Fund for MSME's in South West Bandung, West Java Province during Covid-19

Thus, empowerment is the process of involving the community or group to meet personal needs as well as groups, no empowered community. This is also supported by a review stating that empowerment also emphasizes the process, not solely the output of the process [3]. Empowerment activities have the ultimate goal of making society empowered in their lives. According to many literature of empowerment, the cash fund transfer can be said into government empowerment activity, but how about the non-social distancing act that the receiver has gone through while they propose the stimulus program, this program become contradictive in mean of lives.

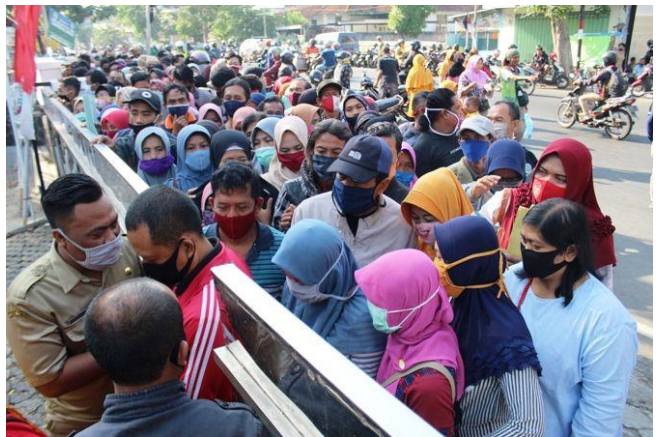

Figure 2. The Queue For BLT UMKM Applicants In Jombang Is Snaking Up To 500 Meters

When the Covid-19 pandemic situation hasn't subsided, not a few of them have ignored health protocols (process). Indeed, the Covid-19 pandemic has not frightened a number of residents who were indeed affected. Even though it was arranged by the police to comply with health protocols, residents did not care. In fact, they were still crammed, ignoring the distance in order to register. "Because I need it, I am not afraid of Corona. I leave everything to Allah," said Hariadi, another resident said to daily bhirawa online Wednesday, January 6, 2021. Ironically, the queue of residents ignores physical distancing. They lined up without maintaining a safe distance from transmission of the Corona virus. Based on Article 25 paragraph (2) point B number 4 of Perwal $11 / 2020$ it is said that there are sanctions in the form of restrictions / termination / dissolution of activities, as a form of support for social and physical distancing calls. However, this was not done by the Social Service even though hundreds of people were crowding and jostling, some even brought their children. Instead, they are increasingly crammed into each other so that their filing files can be prioritized. This situation can be seen as a form of weak Pemko in carrying out the rules that have been set. "The sub-districts, sub-districts and neighborhoods should not be silent looking at this situation, even though they should be the ones most responsible for receiving complaints from residents. people's fear is to prioritize empty stomach contents and support their needs rather than safety from the covid 19 virus, there is a disconnected role for the government in this regard, the role of in-depth education regarding the importance of maintaining health programs and distributing appropriate assistance and not endangering aid recipients.

\section{BACKGROUND THEORY}

The Regional Quarantine initiative step by several local governments can indeed be seen as part of an effort to prevent the spread of the COVID-19 virus. However, this step actually comes out of the standard set out in Law no. 6 of 2018 concerning Health Quarantine ("Health Quarantine Law 2018"), in which to implement Regional Quarantine, the Central Government should first determine the status of Public Health Emergencies, in which the technical procedures for implementing these two matters are further regulated in a Government Regulation implementing regulations [4]. The Health Quarantine Act 2018, until now has not been completed and published. Although the Regional Government may use discretionary reasons such as the one in Law No. 30 of 2014 concerning Government Administration ("Government Administration Law 2014"), however the policy to enforce the Regional Quarantine (Local Lockdown) should not be carried out without transparency and without careful calculations, which in turn ignores the rights of local residents that should be obtained. In a Regional Quarantine situation. When referring to the provisions of Article 7, Article 8, Article 39, Article 52, Article 55, and Article 79 of the 2018 Health Quarantine Law and Article 8 jo. Article 5 of Law No. 4 of 1984 concerning Communicable Disease Outbreaks ("Infectious Disease Outbreak Law 1984"), it states clearly what things are the rights of citizens that must be fulfilled by the Central Government and Regional Governments and related agencies when an infectious disease outbreak occurs, an emergency situation public health, and is in a situation of Regional Quarantine and 
Home Quarantine as well as in Large-Scale Social Restrictions, which includes:

1. The right to basic health services according to medical needs;

2. The right to get food needs and other daily needs;

3. The right to receive the same treatment in the administration of Health Quarantine

4. The government has the right to fulfill the basic necessities of life and fodder for livestock, in which the implementation involves the central government, regional governments, and related parties [5]

For every person who comes from a country and/or area of a Public Health Emergency, he/she is entitled to get services from the Health Quarantine Official which includes:

1. Screening

2. Health Vigilance Card

3. Information on procedures for prevention and treatment of outbreaks

4. Taking specimens/samples

5. Reference

6. Isolation

The right to get compensation for experiencing property losses caused by the efforts to overcome the epidemic; The right to obtain Health Quarantine information as an effort to prevent and eradicate the entry and/or exit of events and/or risk factors that may cause a Public Health Emergency. Referring to the 7 (seven) basic rights of citizens during an outbreak, the status of public health emergencies, home quarantine, and regional quarantine, the Central and Regional Governments must be ready to calculate the budget allocation for funds to fulfill the basic rights of these residents. The government must also prioritize aid and mitigation to prevent disease outbreaks, especially for vulnerable groups, especially the urban poor who live in densely populated settlements and the rural poor who live in rural areas, women, and children, the homeless, informal workers, casual traders, and traders. sidewalks, groups with disabilities, gender, and sexual minority groups, and others, which these groups are often neglected and have difficulty getting access to the rights of their citizens.

The implementation of Territorial Quarantine itself can only be possible as long as the Government has complete considerations related to epidemiological aspects, the size of the threat, effectiveness, resource support, technical operations, economic, social, cultural, and security considerations. Especially in terms of consideration of epidemiological aspects, the Government must have a strong basis for studies regarding the correlation between health patterns and disease and related factors at the population level that are the causes and effects of a potential outbreak of the COVID-19 pandemic.

The various problems that arise in the middle of the community, it is felt necessary to provide a form of community empowerment practice. The main objective is not only to overcome problems related to economic income, but also to make people have the ability to meet their physical, economic and social needs, such as; increase self-confidence, participate in social activities, and be able to independently carry out the tasks of life [6]. Therefore, the practice of community empowerment here is conceived of as an effort or way by which people, organizations and communities are directed to be able to master their lives [7]. With this concept, the practice of community empowerment is not only understood as a change activity carried out from within individuals, communities or organizations but also requires support and encouragement from outside parties, especially support from institutions that have a role in empowerment practices. Empowerment functions at the individual, the family, organizational and collective levels [8]. Individual empowerment increases feelings of value and proactive control such as an increased self-confidence, knowledge and skills. Collective empowerment involves the individual, family and the community to increase their ability to be better organized towards gaining social and political influence. Importantly, empowerment can be facilitated by government and non-government organizations to enable individuals and communities to assist in the management of a disease outbreak [9].

Learning to live with COVID-19 will depend on maintaining low community transmission, on maintaining high social responsibility and on protecting the vulnerable in society [10]. The empowerment model explains how this can be achieve at different levels within society to better protect ourselves and others against COVID-19. Social responsibility can be best maintained over the longterm through collective empowerment alongside localized population controls such as lock-downs and financial incentives. propose the empowerment model of society and health (the empowerment model) builds on the earlier work of the socio-ecological models, the continuum of community empowerment and the theory of the capability approach and systems of thinking. Although the empowerment model is grounded in the westernized literature it can be adapted and applied in different contexts. Below figure 3. are model consist how empowerment stay save during Covid-19:

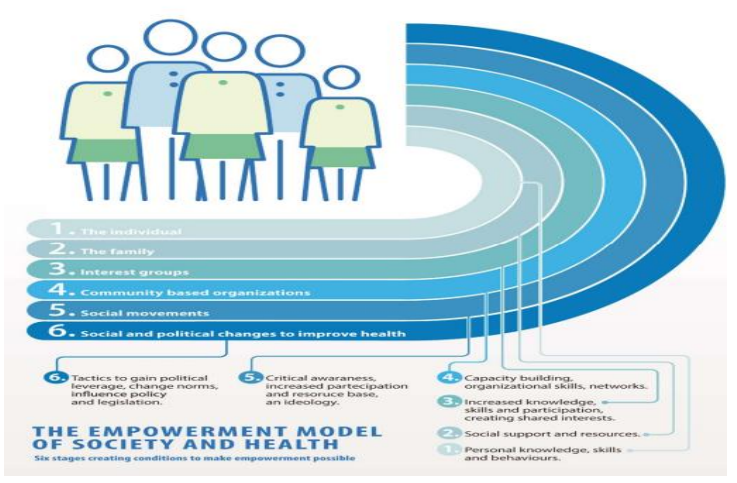

Figure 3. Laverack (2020) The Empowerment Model of Society and Health And COVID-19 


\section{METHODOLOGY}

This research basically describes and analyzes phenomena, event ssocial activities, attitudes, beliefs, perceptions, thoughts of people individually and group. Method is a very important aspect and has a big influence on success or failure of a study, especially to collect data. Research methods is a technique or a way of looking for, obtaining, collecting or recording data, either in the form of primary data and secondary data used for the purposes of compiling a scientific work and then analyze the factors related to the subject matter so that there will be a truth of the data to be obtained. The research method used by researchers is descriptive approach qualitative. This type of research is descriptive research that is a writing describes the actual state of the object under study, according to the circumstances actually at the time of direct research.

In order to obtain a clearer understanding of the descriptive method, the following is stated understanding according to some experts, among others, as follows: Descriptive method is methods used to describe or analyze a research result but not used to make broader conclusions The descriptive method is a method of examining the status of human groups, an object, a set of conditions, a system of thought, or a class of events in the present.

The types of data to be collected in this study consist of primary data and secondary data. The data source of this research is taken directly through observation, interviews, documentation study and literature study. In accordance with the previous explanation, the form of this research is descriptive qualitative. Humans as data collection instruments provide benefits, because humans can be flexible and adaptive, and can use the whole tool his senses to understand something. The research object in this study is a model of direct cash assistance by the Government and the research subjects are recipients of direct cash assistance in Bandung, West Java, Indonesia.

\section{RESULT}

Individuals can benefit from outside intervention to get enabled to ensure themselves as well as other people against Coronavirus and to help during a sickness flare-up. This incorporates assisting people with recognizing issues, for example, how to keep up social removing, and make a move to determine them. Family qualities can be impacted to help singular choices and vested parties can be upheld to build investment, for the individuals to turn out to be fundamentally mindful and to help others during an episode, for example, dispersing basic things. Networkbased associations are urgent in light of the fact that they help to assemble trust and can give a connection between government strategy and the networks through a broad organization of contacts. Social developments can assist with politicizing an issue, give a supported exertion and apply strategies that can impact social and political changes to shield everybody from COVID-19 [11].
Establishing a trusted source(s) of information is important during a disease outbreak to maintain a sense of social responsibility to comply with preventive measures. Person to person communication provides a two-way channel that is especially important to develop a dialogue to clarify the key issues. Rather than health workers educating members of the public, it is sometimes better for the communication to come from a familiar person, or peer, to encourage behavior changes to each other. Peer education has been successful in preventing HIV prevention and drug use among young people (UNICEF, 2012). Health coaching has also been effective in managing disease as well as leading to a marked improvement in medication adherence It helps to identify a realistic goal, such as social distancing, and engages in a dialogue to help people understand what is needed to achieve the goal at a personal level [12]. From the description of the model above, the following is the adoption of a model for the distribution of direct cash assistance which is expected to be able to maintain social distancing and still pay attention to the process:

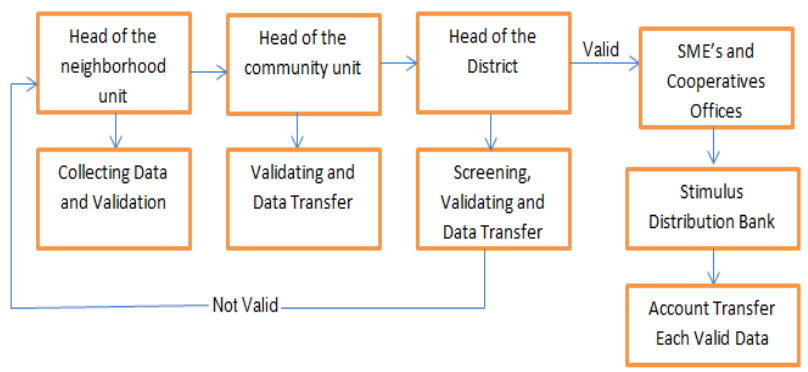

Figure 4 Model in Transferring Economic Stimulus Program in Less Contact

In each step only process by one head each division unit or people who represent, individual who proposed the program no need to come directly to every process, the validation process is carried out by the head of household and household as well as sub-districts, if the data is invalid it will be returned and checked for deficiencies, no need to queue and jostle, it is enough to empower the role of state apparatus to serve the needs of the community. According to the main duties and functions of each public servant, according to the main duties and functions of each public servant, validation can be done online because recording ID cards is also integrated online so tracking data should not be a problem. The accuracy of the data may not be $100 \%$ by coming directly to each process, but the community's right to health protection is fully fulfilled. Data transmission can also be carried out online by scanning documents, so that the disbursement and validation times will be carried out more quickly. The role of security forces in safeguarding the authenticity of data can also be empowered in each household head. Thus data falsification fraud can be minimized. Therefore, business actors wishing to disburse aid funds must do so themselves and bring the necessary documents, such as a KTP. By 
bringing this identity, the document verification and disbursement process will be faster, as a result, hundreds of Micro, Small and Medium Enterprises (MSMEs) queued without paying attention to the Covid-19 health protocol when applying for a Micro Small Business License (IUMK) as a condition for obtaining a budget for direct cash assistance (BLT) affected by Covid-19 from the Central Government. Announcements that deserve assistance and the disbursement process can be escorted through the android application on each household head or applicant, it is not impossible that the Indonesian people are the largest market share of android cellphone users in Asean, how great that we can take advantage of this phenomenon.

\section{CONCLUSION}

The Indonesian government must empower people who are victims of Covid 19 both economically and in health, community empowerment through economic stimuli such as direct cash assistance, at least do not create new problems by queuing and crowds of people cramming to propose the program, the power of education and socialization to the smallest community in the family is the main foundation for how to control the crowd socially and keep implementing health protocols, the government facilitates its citizens to get security rights and economic equality during a pandemic while also protecting public health by not reusing the current model of assistance [13]. Which can be improved in the future, the use of technology, data based and the function of the state apparatus in validating data on submissions can be maximized to prevent crowds and overcrowding when submitting assistance. In the case of direct cash assistance, the concept of empowerment does not support the definition of Indrāvati (2016) and Zimmerman (1995) because they are still dependent on the service provider of assistance, do not pay attention to safety for themselves who propose assistance, there is no collective collaboration between individuals, organizations and family. The suggested model will be further developed in the next research by proposing the use of database-based applications for applications for disbursement of assistance. This step requires combined multidisciplinary research to increase its utility and accuracy.

\section{REFERENCES}

[1] G. Kartasasmita. Pembangunan untuk Rakyat Memadukan Pertum buhan dan Pemerataan. Jakarta: Pustaka Cidesindo, 1996.

[2] A. E. Cahyono, M. U. Kurniawan, S. Sukidin, S. Kantun. Community Empowerment Models of Tourism Village Based on Superior Commodities: Realizing Economic Resilience. The Journal of Distribution Science, 16 (11) (2018) 29-36. DOI: https://doi.org/10.1 $5722 /$ jds.16.11.201811.29
[3] M. H. Hur. Empowerment in terms of theoretical perspectives: Exploring a typology of the process and components across disciplines. Journal of community psychology, 34 (5) (2006) 523-540. DOI: https://doi.or g/10.1002/jcop.20113

[4] D. Telaumbanua. Urgensi Pembentukan Aturan Terkait Pencegahan Covid-19 di Indonesia.QALAMUN A: Jurnal Pendidikan, Sosial, Dan Agama, 12 (1) (2020) 59-70. DOI: https://doi.org/10.37680/qalamuna.v12i01 .290

[5] N. C. Grassly, C. Fraser. Seasonal infectious disease epidemiology. Proceedings of the Royal Society B: Biological Sciences, 273 (16) (2006) 2541-2550. DOI: https://doi.org/10.1098/rspb.2006.3604

[6] E. Suharto. Membangun Masyarakat Memberdayak an Rakyat Kajian Strategis Pembangunan Kesejahteraan Sosial dan Pekerjaan Sosial. Bandung: Refika Aditama, 2005

[7] D. Indrayani. Pengantar Sosiologi Perdesaan. Jakarta: Kencana, 2016.

[8] M. A. Zimmerman. Psychological empowerment: Issues and illustrations. American journal of community psychology, 23 (5) (1995) 581-599.

[9] J. Smith. Overcoming the 'tyranny of the urgent': integrating gender into disease outbreak preparedness and response. Gender \& Development, 27 (2) (2019) 355-369. DOI: https://doi.org/10.1080/13552074.2019. 1615288

[10] F. Borgonovi, E. Andrieu. Bowling together by bowling alone: Social capital and Covid-19. Social Science \& Medicine, 265 (2020) 113501. DOI: https: //doi.org/10.1016/j.socscimed.2020.113501

[11] L. Nissen. Social Work and the Future in a PostCovid 19 World: A Foresight Lens and a Call to Action for the Profession. Journal of Technology in Human Services, 38 (4) (2020) 309-330. DOI: https://doi.org/10 $.1080 / 15228835.2020 .1796892$

[12] M. H. Huffman. Advancing the practice of health coaching: differentiation from wellness coaching. Work place health \& safety, 64 (9) (2016) 400-403. DOI: https://doi.org/10.1177/2165079916645351

[13] A. J. Brooks, M. K. Chen, E. Goldblatt, M. Klatt, B. Kligler, M. S. Koithan, P. Lebensohn. Introducing integrative primary health care to an interprofessional audience: Feasibility and impact of an asynchronous online course. Explore, 16(6), 392-400.DOI: https://doi. org/10.1016/j.explore.2019.08.002 